\title{
Appositeness of Teacher Training for In-Service EFL Teachers in Real Teaching Context
}

\author{
Shankar Dhakal
}

\begin{abstract}
There are various ways for EFL teachers to grow professionally. Attending workshops and training programs are believed to foster their upward mobility. At the same time, different teachers come up with numerous challenges in their classroom with the change of time. So, the learning they had in their college and university level may not always help them to dissolve all the problems in their diverse classroom settings. In this context, this small-scale study is explores whether the insights teachers get from the workshops and the trainings conducted by Nepal English Language Teachers' Association (NELTA) are applicable and they contribute to liquefy the challenges EFL teachers face in their classroom. Drawing on the findings of this study and the support from the literature, it has been justified that training programs help teachers to grow professionally, but they can hardly apply the knowledge and skills they learn in their real classroom situations. With the help of data collected through the interview, it is crystallized that trainings have been almost unsuccessful to help the teachers cope with ever changing professional world.
\end{abstract}

Keywords: Teacher training, EFL, professional development, transfer of training.

\section{Backdrop}

Nepal English Language Teachers' Association (NELTA) was established in 1992, with an objective of setting a common platform for all the teachers of English in Nepal, so as to support their professional development and enhance the overall ELT situation in Nepal. It claims to help English teachers to familiarise with the recent ELT pedagogy involving them in professional development activities such as teacher training programs, workshops, seminars, conferences and so on (NELTA, 2016).
NELTA conducts one-day workshop and training programs in various parts of the country. In these programs, they focus on the current ELT problems and issues and their practical solutions. Hence, it has been providing different training programs to EFL teachers around the nation for their professional development as well as to empower them with the recent developments in ELT in the globe. In this context, I would like to explore whether the insights the trainees get in the training programs and workshops are applicable and handy in their real teaching contexts or the trainings are conducted just for the sake 
of training and what the trainers preach do not fit in the varied classroom settings.

\section{Professional development of teachers}

Teachers have to develop themselves professionally during their teaching career because the knowledge they get about teaching in their college and university education is not sufficient for them for the whole teaching career. With the change of time, they might face new challenges and also new ideas and concepts will be emerging in the field of teaching. So, to keep themselves abreast of the recent methodologies and trends, they have to develop themselves. Stressing the importance of continuous professional development of the teachers, Underhill (1997) has stated that professional development involves teachers in a constant process of learning abouttheir practice and discovering and using their own potential. Similarly, for Richards (1998), professional development requires teachers to create their own personal teaching methodology that takes into account their experience, beliefs and understanding about good teaching.

In addition, the need of the learners will also change with the time, since the change is a continuous process. For this, teachers need to update professionally as Pennington (1990) has stated that every teacher needs professional growth throughout her career.

Teachers can develop professionally in various ways such as taking a new responsibility, self-reading, reflective practice, collaborative learning, attending seminars, training programs, conferences and workshops and so on. In the same vein, Richards (1998) has added that reflection, self-inquiry, self-monitoring and self- evaluation are necessary elements in fostering professional development since they help teachers to be better informed and to evaluate their professional growth, as well as to plan for development.

Additionally, teachers can develop themselves reflecting and evaluating their own practices and modifying them if need be, as Wallace (1991) has stated that teachers' self-evaluation involves reflecting, questioning or engaging in critical reflective inquiry over one's own practice. As Kumaravadivelu (2006) has stated that teachers' self-evaluation and their practice can be considered as a commitment to analysing and evaluating their own teaching acts. So, it helps them to be critical towards their self-practices and, ultimately develop them professionally.

\section{Need of in-service teacher education}

In-service teacher education refers to training of teachers who are already in service. Hence, "It is a supplementary, additional training, which must be given in the teachers' spare time or in time made free by the school authorities" (Mohan, 2011, p. 92). Similarly, every experience he/she undergoes during his/her career, however irrelevant it may appear, may be described as in-service teacher education. In other words, in-service teacher education includes everything that happens to a teacher from the day he/she takes up his first appointment to the day he/she retires whichcontributes, directly or indirectly, to the way in which he/she executes his/her professional duties. "In-service" refers to professional development activities for all employed teachers, thosewith and those without formal qualifications. These programs range from occasional, ad hoc workshops to continuous, comprehensive, career-long programs of professional 
learning. To manage the changes, to enhance professional competence and for professional satisfaction, teachers need continuing professional development for which, inservice training can be one of the ways. Inservice teacher education helps in improving teachers' knowledge and understanding of the subjects they teach, understanding how children learn different subjects developing practical skills and competencies, learning new teaching strategies, learning how to use new technologies, strengthening professionalism and ethics, providing knowledge and skills linked to the everchanging needs of a dynamic society as Uysal (2012) states, " In-service teacher education is a big opportunity for teacher development and for successful implementation of curriculum innovations" (p.12)

\section{Teacher training and/or teacher development}

Teacher training and teacher development are generally, taken synonymously. But, teacher training represents certain course designed for certain time duration, whereas, teacher development continues in the entire profession. However, both contribute to a teacher's improved performance. Highlighting the difference between teacher training and teacher development, Mann (2005) states that

The role of teacher training is to introduce the methodological choices available and to familiarise trainees with that range of terms and concepts that are that 'common currency' of language teachers. But, teacher development is a continuous professional and personal growth that teachers themselves undertake and that is guided by the teachers concerned. (Mann, 2005, p. 104)
Generally, teacher training is time bound with fixed agenda. It is hierarchical. On the contrary, teacher development is related to the need of the individual and it is a continuing process with no fixed agenda. It is a self-directed process. So, for Richards and Nunan (1990), teacher development work towards developing the teachers as an autonomous practitioner, who can independently make decisions, learn from their own actions and solve problems which are unique to their situations. Similarly, Richards and Farrell (2005) have asserted that teacher development involves teachers in understanding themselves and their teaching; in analysing their teaching practices, believes, values and principles; in keeping up-to-date with theories and trends; and sharing their experiences with colleagues. But, teacher training programs are mostly generic and designed basically, to address the common problems of the teachers.

\section{Applying training knowledge in classroom context}

There are several ways for teachers to develop professionally. It is believed that attending workshops and teacher training programs help teachers to develop themselves professionally and make them aware of the recent teaching trends and practices around the globe thereby modifying their teaching practices for better performance. At the same time, when the teachers perform well, it is expected to contribute to the better result of the students. However, what the trainee teachers learn in training programs can be, sometimes difficult to apply in their real classroom context, because of social, cultural, economic and linguistic variations. At the same time, all the teachers have different and unique classroom environment, where the same methods and strategies may not be applicable all the time, as Maley (1990) stresses that the major drawback of traditional training program is 
that they tend to prescribe what teachers need to do irrespective of the diverse working environment each teacher has to face.

Moreover, it is generally accepted that when teachers develop their skills, attitudes and knowledge through workshops and trainings, they perform better, and thereby contributing to the better result of the students. But, a study conducted by Jacob and Lefgren (2004) shows that in-service teacher trainings have no statistically or academically significant effect to increase the achievement of elementary schoolchildren. Similarly, Harris and Sass (2006) studied the effects of various trainings to promote student achievement. They found that there is no evidence that the trainings to the teachers increase student achievement. So, it can be discerned that teacher trainings may not always foster the performance of the teachers and contribute to promote students' learning.

\section{Objectives of the study}

This is a small-scale research study conducted in the Chitwan district interviewing three in-service EFL teachers with an objective of investigating whether the learning the trainee teachers have in training programs and workshops, mainly conducted by NELTA help to foster the performance of teachers and are applicable and classroom-friendly or how practical they are in their real classroom context.

\section{Research methodology and participants}

In this exploratory qualitative study, I have primarily used conversational interview to collect data as Rossman\&Rall 1998 (as cited in Richards, 2003) state "Interviewing is the hallmark of qualitative research" (p. 47). I purposively selected three EFL teachers teaching in different schools in Chitwan district, who attended minimum three training programs conducted by NELTA and interviewed them. In addition, I used different documents, reports and research studies as sources of information. This study adopts semi-structured interview, where "the interviewer is free to follow up a question with additional questions that probe further" (Perry, 2005, p. 119). There was no predetermination of questions, rather the researcher prepared some guidelines or interview themes before interview.

For this study, I purposively selected three EFL teachers having minimum five years of experience in teaching English and attended at least three trainings or workshops conducted by NELTA.

\section{Data analysis procedure}

This section presents the analysis of qualitative data gathered during the faceto-face individual interviews. The data gathered from the interviews were coded and categorised under themes through qualitative techniques. These codes were organised around research objectives and for the ethical reasons, the real identity of the participants were masked using pseudonyms as T1, T2 and T3 while analysing the data.

\section{Findings and discussion}

There may be many ways in which the information gathered in this research study could have been analysed. In this paper, I shall present the findings and discuss them establishing the following themes: Link between the training objectives and the trainees' needs; Feasibility of training in real classroom context; and role of training to improve teachers' performance and productivity. 


\section{Link between training objectives and trainees' needs}

When I asked the participants whether there was the link between objectives of the training programs they attended and their real needs, or whether the trainings were successful to meet their expectations, one of the participants said that he had expected a lot before he attended the session. But, he felt it incomplete after the training and he learnt only limited thing that he was longing for. In the same vein, T1 responded, No, Never. I would be invited to attend the sessionsbut the details would not be given. I would know only the topics of the training. The details would be unfolded only after the training began. I have never found the training sessions valuing the need of the participants. Usually, the trainers come with their pre-designed training modules. The trainees do what the trainers ask them to do. I have never been asked about my needs before the training.

From the discussion above, it can be inferred that training objectives in the training sessions were not designed keeping the real needs of the trainees in mind. The training programs are notcontextual as T3 said, The training sessions were very interesting. However, the participants'ability seems to have been increased and their need would be addressed if the real classroom situation was similar to the training hall situation.

\section{Feasibility of training in real classroom context}

Regarding the feasibility of the training in their real classroom context, the views of the participants were almost similar. One participant said that the trainings were mostly theoretical and they were hardly contextual. So, what he learnt in the training session was very difficult to apply in his classroom context since he did not get any practical tips to deal with different classroom situations. Similarly, when I asked the next participant whether the training met his expectations to resolve classroom problems and situations, he said, I am afraid they have not met my expectations. Despite participating in the training, the problems raised in the training halls were different from the ones we face in our classrooms and the solutions the trainers had given to us in the training halls did not solve our classroom problems.

Similarly, T2 said, Training programs help us grow professionally. They update us. They impart us new knowledge. But, the training programs I have attended were merely the waste of time because I could not apply them in my classroom situation. Frankly speaking, learning did not last for long. The only wealth is the certificate.

Based on the discussion above, it can be inferred that in the present pattern of training, full transfer is a far cry. However, little transfer is a waste of resources. So, it is hard to expect that everything learnt in the training hall can be applied in the classroom. As the participants responded, what the participants learnt in the training sessions could not be transferred to the school situations because everything- the participants, materials, infrastructures, facilities and management was different from the training hall. As a result, the participants may try to apply the training hall learning to the real classroom situation for a couple of days after they return from the training, but the effort fails and they are back to the square one later.

\section{Role of training to improve teachers' performance and productivity}

When the participants were asked whether the trainings helped them to improve their 
classroom performance and productivity, almost all agreed with the opinion that trainings helped to increase their knowledge, but they did not improve their skills, attitude and sense of responsibility. According to them, most of the trainings focused on contents and they impart only content knowledge. They are highly theoretical and are hard to apply in diverse classroom setting. So, they have neither improved their classroom performance nor the result of the students. One of the participants said, The trainers are expert on their own domain and they focus much on the areathey are good at rather than addressing the problems teachers really face in the real classroom teaching.

Similarly, T3 said, I think training is a must for increasing the performance andproductivity of the teachers. They should help teachers to come up with solutions for the problems they encounter in the classroom. They should also connect teachers to the wider community of practice and help them to update their professional practice, but I am afraid. Trainings are not able to address all these.

Based on the discussion above, it can be concluded that theoretical aspects are prevalent in the training sessions, but practical aspects are not emphasised. Training sessions are good, but if they focus the contextual needs, it will be icing on the cake. As the participants said that the trainings always miss the context, due to which they are less helpful to the teachers to improve their classroom performance, even if they attend several training sessions.

\section{Conclusion}

What is to be emphasized today is to encourage teachers to find a way of teaching that is appropriate to their own context. But, the training sessions which are thought to help the teachers to address their daily classroom needs seem to be ineffective. According to the participants, teachers cannot apply all what they learn in the trainings. It is because training patterns have been de-contextualized since each classroom context is unique, which is different from the trainingcontext. So, taking training is one thing, but solving the real classroom problem is a different kettleof fish. In this way, on the basis of the findings, I hope that this mini research will help the EFLprofessionals and other stakeholders to rethink about the teacher training programs and theireducational implication in a meaningful way.) $\dagger$

\section{References}

Harris, D., \& Sass, T. R. (2006). The effects of teacher training on teacher value added. Department of Economics. Florida State University. Available: ftp:// econpapers.fsu.edu.

Jacob, B. A., \& Lefgren, L. (2004). The impact of teacher training on student achievement: Quasi-experimental evidence from school reform efforts in Chicago. Journal of Human Resources, 39(1). University of Wisconsin Press. Available:http://jhr.uwpress.org.

Kumaravedivelu, B. (2006). Understanding language teaching: From method to post method. New Jersey: Lawrence Erlbaum Associates.

Maley, A. (1990). Teacher development explained. Practical English Teaching, 10(4).

Mann, S. (2005). The language teachers' development. Cambridge: Cambridge University Press

Mohan, R. (2011). Teacher education. New Delhi: PHI Learning Limited. 
NELTA (2016). NELTA Objectives. Available: http://nelta.org.np.

Pennington, M. C. (1990). A professional development focus for the language teaching practicum. In J. C. Richards and D. Nunan (Eds.), Second language teacher education. Cambridge: Cambridge University Press.

Perry, J. F. (2005). Research in applied linguistics. New York: Routledge.

Richards, J. C. (1998). Beyond training: Perspectives on language teacher education. New York: Cambridge University Press.

Richards, K. (2003). Qualitative inquiry in TESOL. New York: Palgrave, Macmillan.

Richards, J. C., \& Farrell, T. (2005). Professional development for language teachers: Strategies for teacher learning. Cambridge: Cambridge University Press.

Richards, J. C., \& Nunan, D. (1990). Issues and approaches in teacher education. In J. C. Richards \& D. Nunan (Eds.), Second language teacher education. Cambridge: Cambridge University Press.
Underhill, A. (1997). (Ed.). The teacher development series. In K. Head \& P. Taylor. Readings in teacher development. Oxford: Heinemman.

Uysal, H. H. (2012). Evaluation of an inservice training program for primaryschool language teachers in Turkey. Australian Journal of Teacher Education, 37(7). http://dx.doi.org.

Wallace, M. J. (1991). Training foreign language teachers: A reflective approach. Cambridge: Cambridge University Press. ) $\dagger$

The author: Shankar Dhakal is an M. Phil. (ELE) scholar at Kathmandu University. He has worked as an EFL teacher for more than a decade and a teacher trainer for about five years. He has conducted a mini-research in various EFL issues in Nepal. He is a life member of NELTA. His research interests include critical pedagogy and issues of large EFL classes. 